\title{
Three new species of Begonia sect. Petermannia (Begoniaceae) from Sandaun Province, Papua New Guinea
}

\author{
H.P. Wilson ${ }^{1,2}$, T. Jimbo ${ }^{3}$, A. Hagwood ${ }^{4} \&$ M. Hughes ${ }^{1}$ \\ ${ }^{1}$ Royal Botanic Garden Edinburgh, 20a Inverleith Row, \\ Edinburgh, EH3 5LR, Scotland, U.K. \\ hwilson@rbge.org.uk \\ ${ }^{2}$ Institute of Biodiversity, Animal Health and Comparative Medicine, \\ College of Medical, Veterinary and Life Sciences, University of \\ Glasgow, G12 8QQ Glasgow, Scotland, U.K. \\ ${ }^{3}$ Papua New Guinea National Herbarium, Papua New Guinea \\ Forest Research Institute, P.O. Box 314, Lae, Papua New Guinea. \\ ${ }^{4}$ Johns Hopkins University, 3900 North Charles St., Apt 109, \\ Baltimore, MD 21218, USA
}

\begin{abstract}
Three new species from Begonia sect. Petermannia (Klotzsch) A.DC., Begonia fractalifolia H.P.Wilson \& Jimbo, Begonia aikrono H.P.Wilson \& Jimbo, and Begonia sandaunensis H.P.Wilson \& Jimbo, are described from Sandaun Province in Papua New Guinea. Begonia fractalifolia is known from the type locality and a site c. $130 \mathrm{~km}$ further south, whereas the other two species are only known from their type localities. The IUCN conservation status of each is assessed as Data Deficient.
\end{abstract}

Keywords. Begonia humboldtiana, Begonia malmquistiana, biodiversity, taxonomy, Yapsiei

\section{Introduction}

New Guinea is an exceptionally diverse island, containing up to $10 \%$ of all terrestrial biodiversity in less than $1 \%$ of global land area, with a vascular plant flora of 13,634 known species, though this figure is expected to rise by up to 4000 in the next 50 years (Mittermeier et al., 2003; Hoover et al., 2017; Cámara-Leret et al., 2020). This propensity towards diversity on New Guinea is exhibited by the large genus Begonia L., currently with 94 species accepted from the island (Hughes et al., 2015a), but with hundreds more likely awaiting discovery and description, evidenced by the large proportion of unidentified specimens in herbaria. Some progress has been made on the naming and description of new species (Hughes et al., 2015b; Gagul et al., 2018; Wilson et al., 2019), and even a new section, Begonia sect. Oligandrae M.Hughes \& W.N.Takeuchi (Hughes \& Takeuchi, 2015), but much remains to be done.

A recent ethnobotanical expedition in Sandaun Province, Papua New Guinea resulted in collections of several unknown Begonia species, three of which are 
described as new species below. In May 2018, Hagwood and Jimbo travelled into the upper tributaries of the Sepik River, departing from Green River and botanising in primary rainforests surrounding Yapsiei Station as well as near the village of Kwima approximately 14.5 kilometres downstream. Due to each site's remote location, there has been scant research on the local flora and its ethnobotanical significance. Over the course of three field days in Yapsiei and two in Kwima, Hagwood and Jimbo collaborated with resident research participants to study culturally significant plant species and their medicinal applications, with particular emphasis on treatment for bacterial skin infections. With an increase in logging and oil palm plantation activity in Sandaun Province, it was critical to gather this information while endemic ecosystems were relatively intact.

Previous botanical exploration in the environs of Kwima and Yapsiei have primarily focussed on orchid and tree species, yielding only four Begonia specimens. In all, 19 Begonia collections were made during this expedition, none of which are identifiable as an existing species. This is hardly surprising given the diversity of the genus on New Guinea, propensity within it for micro-endemic species, and paucity of botanical research focusing on the herbaceous plants in this area. Here we describe just three species (from six collections) which were easily identifiable as new to science from the material gathered. The remaining 13 collections made on this expedition may consist of as many as 10 further new species, but the specimens are mostly unisexual or sterile and so unfortunately cannot be described here, highlighting the need for increased collecting effort and taxonomic focus on New Guinean Begonia.

Begonia sect. Petermannia is the most species rich section on New Guinea with 65 species, followed by B. sect. Symbegonia (Warb.) L.L.Forrest \& Hollingsw. (endemic section, 18 species), $B$. sect. Oligandrae (endemic section, 6 species) and B. sect. Diploclinium (Lindl.) A.DC. (5 species) (Hughes et al., 2015a). All three new species described here are assigned to Begonia sect. Petermannia, a large and diverse polyphyletic section common throughout Southeast Asia (Moonlight et al., 2018). The sectional placement is confirmed by the species' caulescent habit (i.e., lacking rhizomes or tubers), protogynous inflorescences, and solitary or paired female flowers (Doorenbos et al., 1998; Kiew et al., 2015).

\section{Taxonomy}

1. Begonia aikrono H.P.Wilson \& Jimbo, sp. nov. (§ Petermannia)

Shares a double-serrate leaf margin with Begonia humboldtiana Gibbs, but is not as deeply serrate, it also lacks white spots on the lamina, the lamina is slightly asymmetric (not markedly so), and the stems are villose (not glabrous). The closest affinity of Begonia aikrono to other New Guinea species is not clear. - TYPE: Papua New Guinea, Sandaun Province, Kwima, 4²9'22.62"S 141 ${ }^{\circ} 5^{\prime} 16.91 " \mathrm{E}, 167 \mathrm{~m}, 16$ May 2018, A. Hagwood et al. LAE91288 (holotype LAE; isotype E). (Fig. 1 \& 2).

Erect to sprawling herb, terrestrial or epiphytic at the base of tree trunks, $20-30 \mathrm{~cm}$ tall, with leafy stems held more or less horizontal. Stems becoming woody with age, 

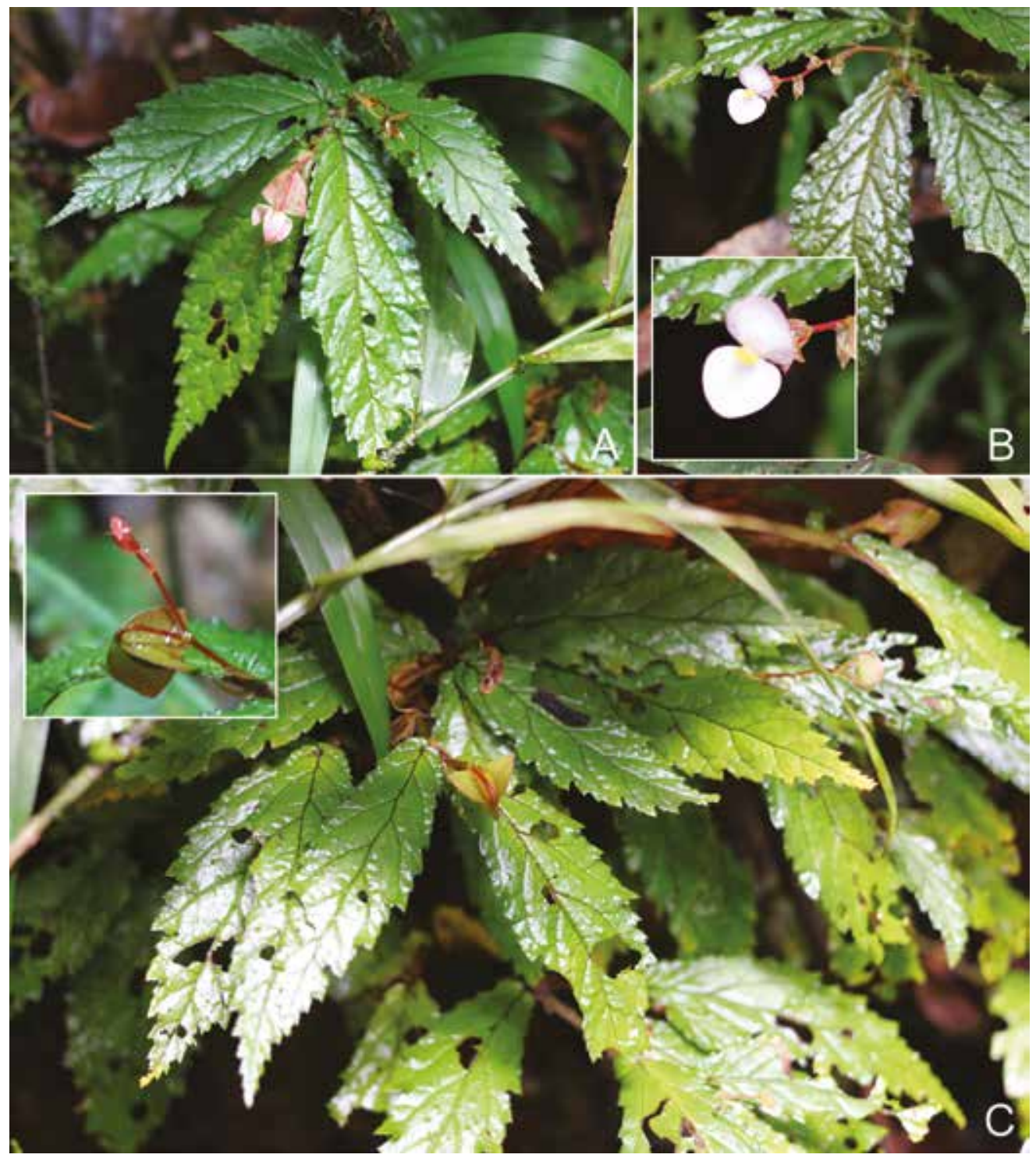

Fig. 1. Begonia aikrono H.P.Wilson \& Jimbo. A. Habit and female flower. B. Male inflorescence and male flower (inset). C. Habit and ripening fruit (inset) on a recurved pedicel. A \& $\mathrm{C}$ from LAE91288; B from LAE91289. (Photos: A. Hagwood).

villose with short curled hairs c. $1 \mathrm{~mm}$ long, basal internodes c. $5 \mathrm{~cm}$ long, leafy stem internodes 1-2 cm long. Stipules deciduous, narrowly lanceolate, c. $7 \times 3 \mathrm{~mm}$, with a caudate tip c. $5 \mathrm{~mm}$ long, keeled, villose on the keel. Leaves petioles c. $5 \mathrm{~mm}$ long, hairs as on the stem; lamina lanceolate, $(4-) 6-11 \times(2-) 2.5-3 \mathrm{~cm}$, slightly asymmetric, base oblique, basal lobe c. $7 \mathrm{~mm}$ long, adaxial surface mid green, veins darker and sunk into the lamina, lamina appearing glabrous at first glance but with sparse minute setae between the veins, abaxial surface puberulent on primary and secondary veins, glabrous between the veins, margin serrate-serrulate, teeth tipped with a short hair, apex 


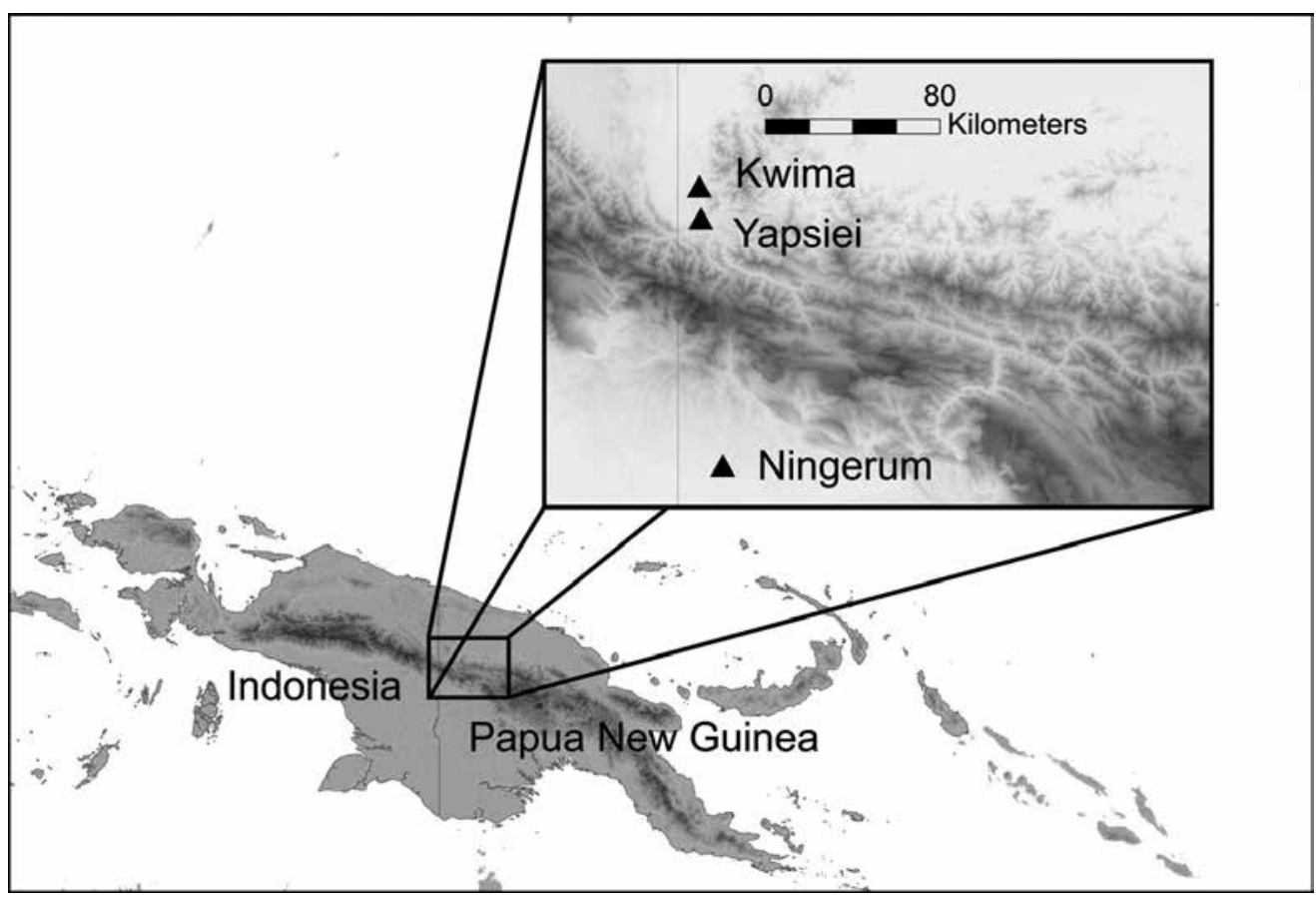

Fig. 2. Distribution of Begonia aikrono (Kwima), B. fractalifolia (Kwima and Ningerum), and B. sandaunensis (Yapsiei) in Papua New Guinea.

acuminate; venation pinnate, sunken above. Inflorescences unisexual or bisexual, if bisexual then protogynous with male inflorescence terminal, cymose, c. $6 \mathrm{~cm}$ long, c. 7 flowers, opening sequentially, one at a time. Bracts lanceolate, c. $5 \times 2 \mathrm{~mm}$, glabrous, shortly caudate. Male flowers pedicels pink, c. $7 \mathrm{~mm}$ long; tepals 2, subcordate, c. 8 mm diam., greenish pink outside, pale pink when open with veins visible; androecium horizontally flattened, stamens c. 40 , filaments c. $0.25 \mathrm{~mm}$ long in outer stamens, to $1 \mathrm{~mm}$ in central stamens; anthers light yellow, oblong, hooded, c. $1 \mathrm{~mm}$ long, slits unifacial c. $1 / 3$ of the anther length. Female flowers solitary, terminal or at the base of the male portion of the inflorescence; pedicel c. $10 \mathrm{~mm}$ long with very short hairs; ovary 3-locular, placentation axile with two placental lamellae per locule, pale green with pink wings, c. $12 \times 15 \mathrm{~mm}$ including the wings, wings subequal, roundedtriangular, truncate at apex, with short hairs on the margin; locular part ellipsoid, c. $10 \times 4 \mathrm{~mm}$; tepals 5 , ovate-lanceolate, c. $8 \times 5 \mathrm{~mm}$, white with pink flush towards the apex, glabrous; styles 3, stigmas fan shaped. Fruit on a glabrous, stiff, recurved pedicel c. $2 \mathrm{~cm}$ long; total size including wings c. $14 \times 20 \mathrm{~mm}$, locular part c. $12 \times 4$ $\mathrm{mm}$, wings subequal, rounded-triangular, c. $12 \times 4 \mathrm{~mm}$, truncate at apex.

Distribution. Known only from the type locality in Kwima environs of Sandaun Province.

Habitat. Lowland intact primary rainforest, away from human disturbance, on dead logs or terrestrial, growing in association with species of Raphidophora Hassk., Dianella 
Lam., Procris Comm. ex Juss., Elatostemma J.R.Forst. \& G.Forst., Selaginella P.Beauv. and Flagellaria L.

Etymology. The epithet is the local name in Mianmin.

Local names. Aikrono (Mianmin) and Taman (Abau).

Provisional IUCN conservation assessment. Data Deficient (IUCN Standards and Petitions Subcommittee, 2017). Nothing is known about the distribution of this species other than its occurrence at the type location; there is a wide variance in range size of Begonia species on New Guinea, and it is appropriate to wait for further information to better assess the level of threat.

Notes. The leaves and habit are reminiscent of thin-leaved Urticaceae.

Additional specimens examined. NEW GUINEA: Papua New Guinea: Sandaun Province (West Sepik Province), Kwima, 4²9'22.62"S 141'5'16.91"E, 167 m, 16 May 2018, Hagwood et al. LAE91289 (E, LAE).

2. Begonia fractalifolia H.P.Wilson \& Jimbo, sp. nov. (§ Petermannia)

The highly dissected leaf is remarkable and unique among currently-described New Guinea Begonia. Begonia bipinnatifida J.J.Sm. is the only other species in B. sect. Petermannia with multi-divided leaves, but it is glabrous (not with densely villose stems and petioles), has a more finely divided lamina, and has more symmetric fruit with 3 locules (not 2). - TYPE: Papua New Guinea, Sandaun Province, Kwima, $4^{\circ} 29^{\prime} 27.93 " \mathrm{~S} 141^{\circ} 5^{\prime} 14.54 " \mathrm{E}, 139 \mathrm{~m}, 16$ May 2018, A. Hagwood et al. LAE91285 (holotype LAE; isotype E). (Fig. 2 \& 3).

Fleshy sprawling herb, epiphytic on tree trunks in seasonally flooded forest, occurring at c. $1 \mathrm{~m}$ above ground. Stems green, fleshy, lower stem ascending, rooting into substrate at the nodes, leafy stem horizontal, $25-30 \mathrm{~cm}$ long, densely villose at apex, hairs pale green, 3-5 mm long, becoming glabrous towards base, internodes $0.75-2$ $\mathrm{cm}$ long, shorter towards apex. Stipules deciduous, lanceolate, c. $10 \times 5 \mathrm{~mm}$, pale green, translucent, not keeled, with a mucronate tip 3-4 mm long, glabrous. Leaves petioles c. $1 \mathrm{~cm}$ long, villose, hairs 3-4 mm long, pale green; lamina lanceolate, 6-10 $\times 3-4 \mathrm{~cm}$, slightly asymmetric, base oblique, basal lobe c. $7 \mathrm{~mm}$ long, adaxial surface pale green, appearing glabrous, but with minute setae between the veins, abaxial surface very pale green, main veins villose, hairs 2-3 $\mathrm{mm}$ long near the petiole, to $1 \mathrm{~mm}$ at apex, near glabrous between veins, with a few scattered short hairs; margin bipinnately dissected to within $5-15 \mathrm{~mm}$ of the midrib, apex acuminate, venation pinnate. Inflorescences unisexual, cymose, male terminal with 2-3 flowers, female axillary or terminal with 1-2 flowers. Bracts ovate, c. $1 \times 0.5 \mathrm{~cm}$, glabrous, pale green, translucent, not keeled, with a caudate tip 3-4 mm long. Male flowers pedicel pinkishbrown; tepals 2 , subcordate, c. $12 \times 10 \mathrm{~mm}$, very pale green with pink base, pink 


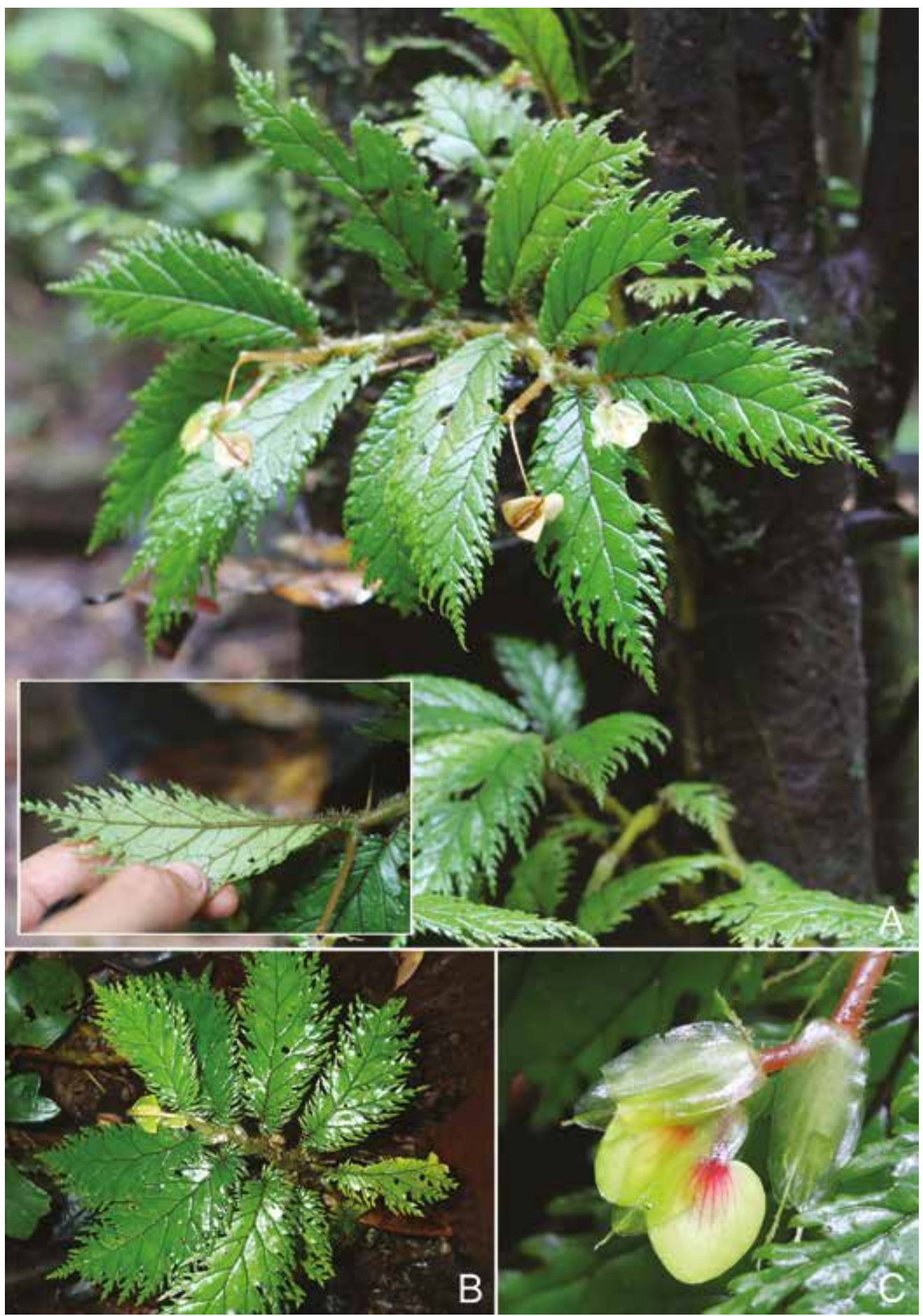

Fig. 3. Begonia fractalifolia H.P.Wilson \& Jimbo. A. Epiphytic specimen, with inset showing hairs on stem and petioles. B. Terrestrial specimen, showing recurved fruit. C. Male inflorescence, showing caudate bracts. All from LAE91285. (Photos: A with inset \& C, A. Hagwood; B, T. Jimbo). 
striped, anthers not seen. Female flower not seen. Fruit with inconspicuous hairs near base, on a recurved, sericeous pedicel c. $2.5 \mathrm{~cm}$ long, ovary bilocular, placentation axile with two placental lamellae per locule, 3 wings; the two smaller wings forming a splash cup, and one larger wing orienting the fruit, dehiscence along two smaller wings only; smaller wings triangular, c. $6 \mathrm{~mm}$ long, larger wing rounded with truncate base, c. $12 \mathrm{~mm}$ long.

Distribution. Known from the type locality of Kwima environs in Sandaun Province, and also from a similar altitude south of the main range near Ningerum in Western Province.

Habitat. Lowland intact primary rainforest away from human disturbance, epiphytic on tree trunks, growing in association with Acanthus L. and Elatostema novoguineense Warb.

Etymology. After the repeated divisions of the leaf lamina margin; like a fractal.

Local names and uses. Taman (Abau). The leaves are eaten steamed with vegetables and meat.

Provisional IUCN conservation assessment. Data Deficient (IUCN Standards and Petitions Subcommittee, 2017). Nothing is known about the distribution of this species other than its occurrence at two locations; there is a wide variance in range size of Begonia species on New Guinea, and it is appropriate to wait for further information to better assess the level of threat.

Notes. The collections Royen \& Sleumer 7507 (L2471298) and Royen \& Sleumer7644 (L2471296) in the Naturalis Herbarium in Leiden have a similar divided leaf margin to Begonia fractalifolia. They are currently determined as Begonia humboldtiana but differ considerably from the type of that name. However, they have a much sparser and shorter indumentum on the stems and petioles than we observe in Begonia fractalifolia; although the specimens may be allied to our new species, we do not consider them to be conspecific. Begonia fractalifolia is unusual in Begonia sect. Petermannia in having 2-locular ovaries.

Additional specimen examined. NEW GUINEA: Papua New Guinea: Western Province, Kiunga Subdistrict, 5 km NE of Ningerum, 180 m, s.d., Anon. HYN253 (LAE [LAE217339]).

\section{Begonia sandaunensis H.P.Wilson \& Jimbo, sp. nov. (§ Petermannia)}

Shares a narrow lanceolate leaf lamina, much branched habit and fruit on recurved pedicels with Begonia malmquistiana Irmsch. (but is much less hairy), the leaves are sparsely spinose above (not densely shortly pilose), and the stem has minute scattered 
hairs (not with dense erect villose hairs). The sparsely bullate leaves are diagnostic, with the bullae often being a striking deep pink. - TYPE: Papua New Guinea, Sandaun Province, Yapsiei, 4³7'32.21"S 1415'27.65"E, 192 m, 13 May 2018, A. Hagwood et al. LAE91157 (holotype LAE; isotype E). (Fig. 2 \& 4).

Terrestrial much-branched erect herb to 30-40 cm tall. Stems branching, slender, woody, brownish red, maroon flushed at nodes, with minute scattered hairs, nodes swollen, internodes 5.5-8 cm long. Stipules deciduous, lanceolate, c. $8 \times 5 \mathrm{~mm}$, keeled, apex acuminate, glabrous. Leaves petioles $0.7-1.5 \mathrm{~cm}$ long, with minute scattered hairs; lamina glossy, narrowly lanceolate $4.5-10 \times 1.5-4 \mathrm{~cm}$, base oblique, basal lobe c. $2 \mathrm{~mm}$ long, adaxial surface dark green with a dark pink flushed margin, with striking deep pink spots 4-8 $\mathrm{mm}$ diam., larger spots with central bullae in darker pink, conical, with an acuminate tip, lamina sometimes uniform dark green (LAE91148), abaxial surface pale pinkish green, venation pink, glabrous; margin serrulate, apex acuminate; venation pinnate, veins sunken above. Inflorescences bisexual, terminal, protogynous, female flowers basal, usually 1 , occasionally 2 , male inflorescence cymose with 2-5 flowers. Bracts caducous, minute, c. $2 \times 0.5 \mathrm{~mm}$, shortly caudate. Male flowers pedicels pink, c. $5 \mathrm{~mm}$ long; tepals 2 , cordate, c. $7 \times 8 \mathrm{~mm}$, pale pink with darker venation; androecium horizontally flattened, stamens c. 40 , anthers c. $0.75 \mathrm{~mm}$ long, outer filaments c. $0.5 \mathrm{~mm}$ long, increasing to $1 \mathrm{~mm}$ long in centre of flower, unifacial dehiscence by slits c. $0.25 \mathrm{~mm}$ long. Female flowers not seen. Fruit on a stiff recurved pedicel c. $18 \mathrm{~mm}$ long, ovary glabrous, capsule pink with a green flush at base of the ovary when unripe, $16 \times 19 \mathrm{~mm}$ including the wings, ovary 3-locular, locular part ellipsoid, c. $18 \times 4 \mathrm{~mm}$, placentation axile with two placental lamellae per locule; wings 3 , subequal rounded at base, truncate at apex, largest wing c. $15 \times 8 \mathrm{~mm}$, smaller wings c. $13 \times 6 \mathrm{~mm}$.

Distribution. Known only from the type locality in Yapsiei, Sandaun Province.

Habitat. Lowland primary rainforest, open with partial disturbances from clearing of trees for a walking track. Observed growing alongside the track, in black sticky soil with deep leaf litter, with the other side of the track dominated by typical secondary understorey species such as Schismatoglottis Zoll. \& Moritzi, Selaginella, Thelypteris Schmidel, and also occurring on a rocky slope. The area occasionally floods when it rains.

Etymology. From the name of the province, Sandaun (Tok Pisin for "sun down", as the province is located in the west of Papua New Guinea where the sun sets).

Local names and uses. Kokoyano (Mianmin). The leaves are mixed with ginger and boiled, creating a tea given to asthmatic women as treatment for shortness of breath.

Provisional IUCN conservation assessment. Data Deficient (IUCN Standards and Petitions Subcommittee, 2017). Nothing is known about the distribution of this species 


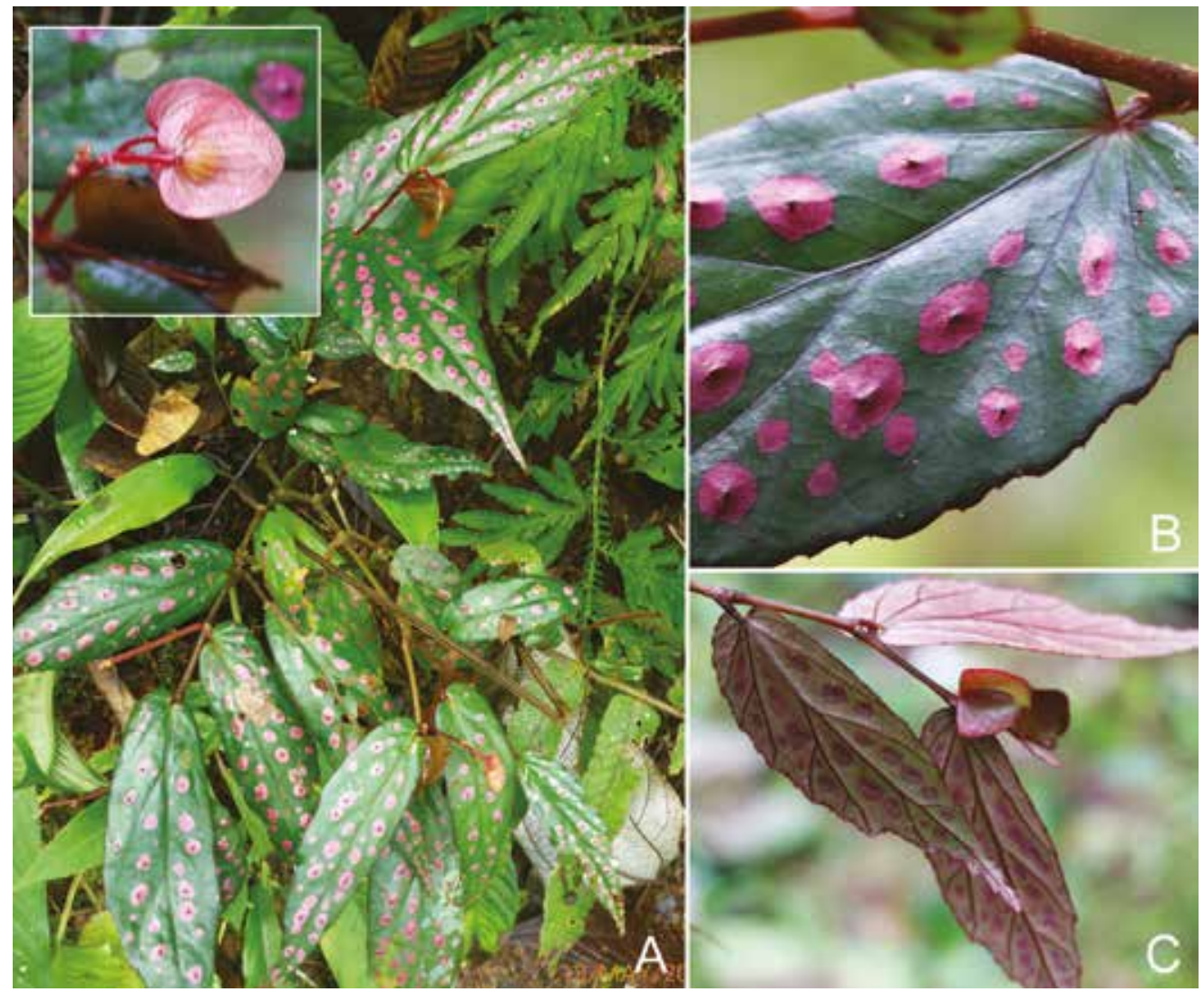

Fig. 4. Begonia sandaunensis H.P.Wilson \& Jimbo. A. Habit (inset: male flower buds). B. Upper surface of leaf lamina showing dark pink bullae .C. Underside of leaf lamina and fruit on a stiff recurved pedicel. D. Male flower buds. All from LAE91157. (Photos: A, T. Jimbo; A inset, B \& C, A. Hagwood).

other than its occurrence at the type location; there is a wide variance in range size of Begonia species on New Guinea, and it is appropriate to wait for further information to better assess the level of threat.

Additional specimens examined. NEW GUINEA: Papua New Guinea: Sandaun Province (West Sepik Province), Yapsiei Station, 437'32.62"S 1415'30.09"E, 178 m, 13 May 2018, Hagwood et al. LAE91148 (E, LAE); Yapsiei Station, 4³7' 29.17"S 1415'20.17"E 190 m, 13 May 2018, Hagwood et al. LAE91386 (E, LAE).

ACKNOWLEDGEMENTS. The authors are grateful to the people of Yapsiei Station and Kwima who shared their time, hospitality, and knowledge with us. Inock Aika, Benson Wairom, and Andy Mai delivered extraordinary help as field assistants throughout our expedition. We wish to thank staff at the Papua New Guinea National Herbarium and Forest Research Institute in Lae, particularly Robert Kiapranis, Bernard Sule, Peter Homot, Kipiro Damas, Thomas 
Magun and Penniel Lamei for support. At the Royal Botanic Gardens, Kew, we are grateful to Marie Briggs, Rodrigo Cámara-Leret, Gemma Bramley, Tom Prescott, and Tim Utteridge for pre-fieldwork training. This research was funded by a National Geographic Early Career Grant and a U.S. Fulbright Study/Research Award, and the findings here do not reflect the views of the National Geographic Society or the U.S. Department of State. Both Miguel Vilar at National Geographic and staff at the U.S. Embassy in Port Moresby have remained unflagging in their support of this work. The Royal Botanic Garden Edinburgh is supported by the Scottish Government's Rural and Environment Science and Analytical Services Division. This paper is part of the first author's PhD research, supported by the M.L. MacIntyre Begonia Trust.

\section{References}

Cámara-Leret, R., Frodin, D.G., Adema, F., Anderson, C., Appelhans, M.S., Argent, G., Arias Guerrero, S., Ashton, P., Baker, W.J., Barfod, A.S. et al. (2020). New Guinea has the world's richest island flora. Nature 584, 579-583.

Doorenbos, J., Sosef, M.S.M. \& De Wilde, J.J.F.E. (1998). The sections of Begonia including descriptions, keys and species lists (Studies in Begonia VI). Agric. Univ. Wageningen Pap. 98: 1-266.

Gagul, J.N., Sands, M.J.S., Gideon, O. \& Hughes, M. (2018). A revision of Begonia sect. Symbegonia on New Guinea. Edinburgh J. Bot. 75(2): 1-33.

Hoover, J.D., Kumar, S., James, S.A., Leisz, S.J. \& Laituri, M. (2017). Modeling hotspots of plant diversity in New Guinea. Trop. Ecol. 58: 623-640.

Hughes, M. \& Takeuchi, W. (2015). A new section (Begonia sect. Oligandrae sect. nov.) and a new species (Begonia pentandra sp. nov.) in Begoniaceae from New Guinea. Phytotaxa 197: 37-44.

Hughes, M., Moonlight, P.W., Jara, A., Tebbitt, M.C., Wilson, H.P. \& Pullan, M. (2015a). Begonia Resource Centre. http://padme.rbge.org.uk/begonia. Accessed 28 Oct. 2019.

Hughes, M., Barber, S., Heatubun, C.D. \& Gagul, J. (2015b). Begonia yapenensis (sect. Symbegonia, Begoniaceae) a new species from Papua, Indonesia. Eur. J. Taxon. 119: $1-6$.

IUCN Standards and Petitions Subcommittee (2017). Guidelines for Using the IUCN Red List Categories and Criteria. Version 13. Prepared by the Standards and Petitions Subcommittee.

Kiew, R., Julia, S., Repin, R. \& Ahmad, J.A. (2015). A Guide to Begonias of Borneo. Kota Kinabalu: Natural History Publications (Borneo).

Mittermeier, R.A., Mittermeier, C.G., Brooks, T.M., Pilgrim, J.D., Konstant, W.R., Da Fonseca, G.A.B. \& Kormos, C. (2003). Wilderness and biodiversity conservation. Proc. Natl. Acad. Sci. U.S.A. 100: 10309-10313.

Moonlight, P.W., Ardi, W.H., Padilla, L.A., Chung, K.-F., Fuller, D., Girmansyah, D., Hollands, R., Jara-Muñoz, A., Kiew, R., Leong, W.C. et al. (2018). Dividing and conquering the fastest-growing genus: Towards a natural sectional classification of the mega-diverse genus Begonia (Begoniaceae). Taxon 67: 267-323.

Wilson, H.P., Paul, O. \& Hughes, M. (2019). Begonia maguniana (Begoniaceae, Begonia sect. Oligandrae), a new species from New Guinea. Edinburgh J. Bot. 77(1): 119-125. 